\title{
Borehole Logs and Physico-chemical Investigation of Some Presumptive Springs in Akoko, South-western Nigeria
}

\author{
Cyril Chibueze Okpoli \\ Department of Geology, Adekunle Ajasin University, Akungba-Akoko, Nigeria

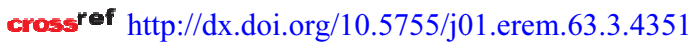

(Received in May, 2013; accepted in September, 2013)

\begin{abstract}
A geophysical investigation involving the use of Schlumberger configuration and physicochemical parameters of water samples has been conducted in twenty (20) selected areas of Akoko in Ondo state, south-western Nigeria, with a view of mapping presumptive springs with respect to depth, thickness, resistivity and sediment that have appreciable yield. The data obtained were interpreted by the computer iteration process and have A, HA, H and Q typical curve types as well as topsoil, weathered/fractured layer, and fresh basement. The focus of the borehole log section is a weathered/fractured layer of appreciable thickness in all locations for springs formation and seasonal yield. Physico-chemical parameters of the water samples have been collected with $\mathrm{pH}$ ranging from 6.57 to 7.20 , EC varying between $1.2 \times 10^{2}$ to $4.2 \times 10^{2}$ (uhr/cm), TDS ranging from 0.01 to 0.55 , turbidity from 0.01 to 0.1 , DO from 7.8 to $9.6(\mathrm{mg} / \mathrm{l})$, BOD from 2.8 to $4.8(\mathrm{mg} / \mathrm{l})$ and COD from 1.6 to $6.4(\mathrm{mg} / \mathrm{l})$, with the temperature of $25^{\circ} \mathrm{C}$ to $26^{\circ} \mathrm{C}$, which may be from slightly acidic to slightly alkaline. Most of the analyzed samples meet the fixed threshold limit by WHO for drinking purpose of below $10 \mathrm{mg} / \mathrm{l}$ values, except the COD and the temperature which are higher than the WHO recommended value by 0.4 and 0.6 , respectively, in the first phase of location 3,5, and 6. People in these locations are likely to have cancer, hence; water purification is recommended before it could be considered safe for drinking.
\end{abstract}

Keywords: vertical electrical sounding (VES), physico-chemical, basement, resistivity and spring water

\section{Introduction}

Akoko areas in south-western Nigeria are not exempted from the world water crisis which is affecting other countries in many parts of the world. The assessment of borehole and physico-chemical quality status is essential for socio-economic growth and development (Ishaku 2011).

The capacity of water to accommodate microbial pathogens and to cause subsequent illness is well documented in both developed and developing countries (Wright et al. 2004). Water like air is one of the most indispensable compounds in life. It is a universal solvent with supplies from wells, springs, rivers, boreholes, lakes, streams, etc. Most of rural water sources for drinking are traditional ones, such as dams, wells, rivers, streams, ponds, which might accommodate waterborne and vector borne diseases (Fenwick 2006). Lack of safe potable water and improved sanitation have been attributed to the occurrence of about $80 \%$ of all reported cases of diseases in developing world (UNESCO 2006). Chemical composition of water may be rendered unfit for human consumption, and thus may lead to illhealth. It is known that a lot of waterborne disease epidemics have been preceded by customer complaints about aesthetic water quality problems (Hrudey and Hrudey 2007). These and several other factors make the groundwater unfit for drinking without treatment (Raymond 1992). The extent of 
treatment needed is determined by the quality of the groundwater source (Macrea et al. 1993). Research has shown that rural water wells are not tested as suggested by professionals, and are contaminated with pathogens and chemicals from various sources (Charrois 2010). Some other research has shown that $33 \%$ of documented outbreaks of water-related infections could be attributed to groundwater systems (Reynolds et al. 2008).

Fieldwork studies have also shown that aquifers in crystalline basement terrains are highly localized and are mainly controlled by weathered regoliths, and secondary porosities resulting from joints and fractures (Adelusi et al. 2000; Bala and Ike 2001; Olorunfemi et al. 2001; Abdullahi 2005). The potentiality of fractured crystalline rocks to store, transmit and yield appreciable quantity of water depends on thickness and continuity of fractures (Bayode 2000). Because of the discontinuous (localized) nature of basement aquifer, successful exploitation of groundwater in basement terrains requires proper understanding of geo-hydrological characteristics.

The Federal Ministry of Health presented statistics in 1994 that only about $30 \%$ of Nigerians have access to potable water (Dada and Ntukekpo 1997 while in the same year, United Nations estimated that 1.2 billion people lacked access to potable water globally (Oyeku et al. 2001). These springs are not potable, and to monitor potability and safety of this water, a physico-chemical analysis must be assessed to see their conformity with regulatory standards. This work serves as preliminary assessment for careful evaluation of physico-chemical analysis of the springs and boreholes and carries a hope that the results will provide informative update on the quality of water from these sources in line with the World Health Organization (WHO) standards.

This study has applied an electrical resistivity method (vertical electrical sounding) and physicochemical analyses of a selected spring to determine groundwater subsurface geometry and quality in the parts of Akoko areas of Ondo state, south-western Nigeria

\section{Geology of the study area}

The study area is the selected locations in Akoko areas of Ondo state, south-western Nigeria as shown in (Figure 1). The area lies within the Precambrian basement complex terrain in south-western Nigeria and has been affected by the Pan African orogeny. Major lithologic units include the migmatite gneiss complex which is made up of three main lithologies: the early gneiss; the amphibolites, the biotite-gneiss and Pan African granites (Rahaman and Ocan 1978). Moreover, minor pegmatite vein and quartz vein intrusions and noticeable geologic structures include faults, folds and joints. Rahaman (1976) recognized that the migmatite-gneiss complex might have resulted from a complex association of a deformative, shearing, folding, granitization and migmatization process. A barrovian type of metamorphism has affected the area and metamorphic grade is from green schist to amphibolite facies (Rahaman 1989). Figure 2 shows the location relief map of the study area indicating longitude, latitude and elevation of the study areas.

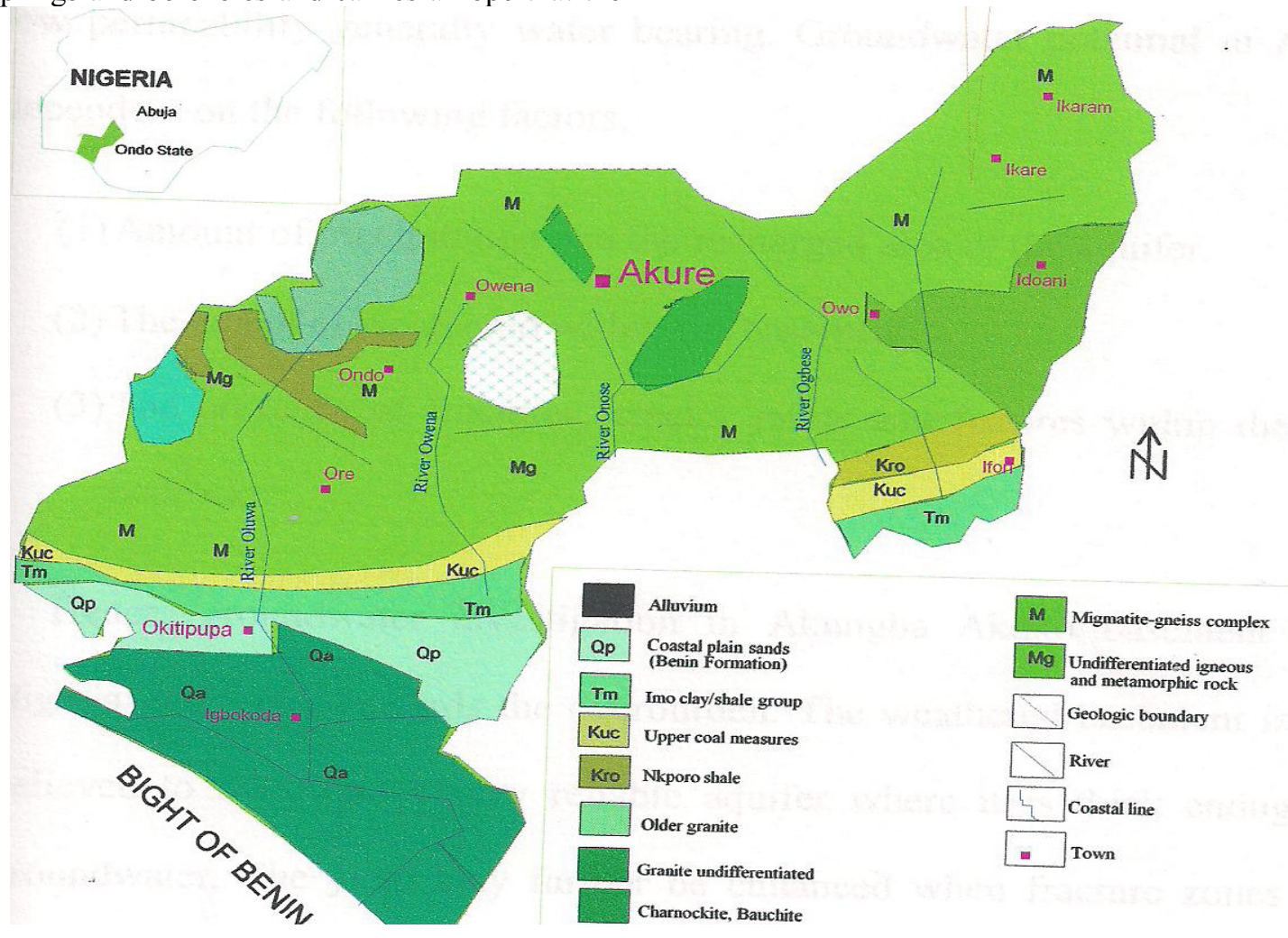

Fig.1. Geological map of Ondo State (Geological survey of Nigeria, Ondo State, 1989) 


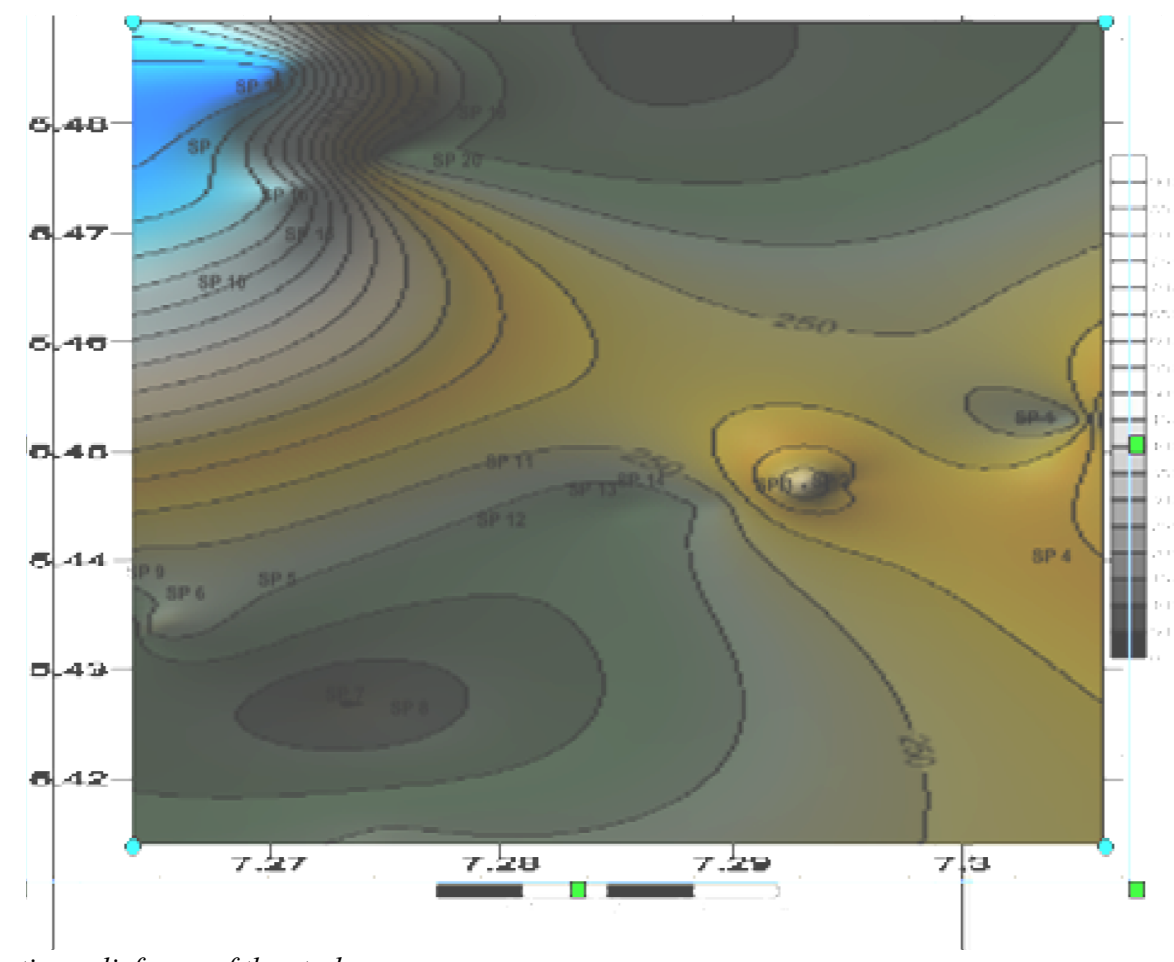

Fig. 2. Location relief map of the study area

\section{Materials and methods}

In this study, the vertical electrical sounding (VES) using Schlumberger array was employed. Schlumberger is the most widely used of all other configurations in depth sounding techniques because of its high probing capabilities in groundwater investigation (Ako, 1996). The current electrode separation was varied between 2 and $60 \mathrm{~m}$. The data were collected at twenty locations using the ABEM SAS 1000 terrameter. The apparent resistivity values obtained from the field were plotted against half current electrode spacing on log - log graph paper. The initial interpretation of the VES data accomplished using a conventional partial curve matching can be regarded as preliminary interpretation of the field curves. It produces the parameter needed \{each layer resistivity and thickness values\} for computer iteration. The field data and the obtained parameter for partial curve matching result serve as input into the system for computer iteration, using WINRESIST version 1.0 software, which in turn displays the resultant theoretical curves. The parameters were subsequently varied until that which was considered the best fit between the field and the theoretical curves obtained for VES station. A particular model was considered acceptable at 10\% error level, as proposed by Barker et al. (1996).

\subsection{Chemical Analysis of Samples}

Temperature values of the water sample were measured in the field with the aid of potable thermometer and some of them were analyzed in the laboratory according to the standard method (Apha 1985).
$\mathrm{pH}$ of the sample of effluent was defined as specified in the standard method (Apha 1985).

Biochemical oxygen demand (BOD) of the samples was determined using the unmodified Wrinkle's method specified in a standard method (Jipha 1985).

$\left\{B O D_{5}=D_{0}-D_{S}\right\} X P=\{M g / L\}$

where:

$\mathrm{D}_{0}$ - $\quad$ the day zero dissolved oxygen;

$\mathrm{D}_{5}-\quad$ is the day five dissolved oxygen;

$\mathrm{P}$ - $\quad$ is the fraction of dilution and is given as:

$P=\frac{\text { Final volume used }}{\text { Initial volume taken }}$

Chemical oxygen demand (COD) of the samples was determined using the reflux method as specified in a standard method (Apha 1985).

$\operatorname{COD}\left\{\frac{M g}{L}\right\}=\frac{\{a-b\} \times N \times 800}{\text { MI of sample used }}$

where:

A - Ml of Fe $\{\mathrm{NH}\}_{2}-\left\{\mathrm{SO}_{4}\right\}_{2}$ used for blank;

$\mathrm{N}$ - normality of $\mathrm{Fe}\{\mathrm{NH}\}_{2}-\left\{\mathrm{SO}_{4}\right\}$ used;

$\mathrm{B}$ - Ml of $\mathrm{Fe}\{\mathrm{NH}\}_{2}-\left\{\mathrm{SO}_{4}\right\}$ used for sample.

Total Dissolved Solid (TDS). Sample analysis for total and dissolved solid was evaporated and filtered, respectively, as specified in a standard method (Apha, 1985).

Total solid in $M g / l=1000\left\{w_{2}-w_{1}\right\}$

where:

$\mathrm{W}_{2}$ - weight of evaporation dish;

$\mathrm{W}_{1}$ - weight evaporating dish and residue. 


$$
\text { Dissolved solid in } M g / l=1000\left\{w_{2}-w_{1}\right\}
$$

\section{Results}

Resistivity results show a delineation of three to four subsurface horizons, namely, the top soil, weathered basement, fracture basement and fresh basement. The fractured basement rock aquifers occur immediately beneath weathered basement rock aquifers in most places and serves as a main source of water for the spring within the study areas. The curve types are $\mathrm{A}, \mathrm{H}, \mathrm{Q}$ and $\mathrm{HA}$ : $\mathrm{A}$ curve type $\left\{\mathrm{P}_{1}<\mathrm{P}_{2}<\mathrm{P}_{3}\right\}$ is a three layer curve, it is composed of topsoil, clayey, weathered basement and fresh bedrock. Three layer curves occurred in the first phase of VES location $7 \& 9$, and second phase of VES location 110 , while $1-6,8$ and 10 as well as VES 5 have a four layer model in the first phase and second phase of locations, respectively. It is predominant of all curve types, it covers about $20 \%$ of the total curve type. Geoelectric sequence of $\mathrm{H}$ type $\{\mathrm{P} 1>\mathrm{P} 2<\mathrm{P} 3\}$, it is a three layer sequence with a clayey lateritic layer, weathered layer and fracture / fresh basement. It is found to occur in VES location 10, it covers about $10 \%$ of the total curve type. The geoelectric sequence of HA curve type $\left\{\mathrm{P}_{1}>\mathrm{P}_{2}<\mathrm{P}_{3}<\mathrm{P}_{4}\right\}$, is topsoil, lateritic / sandy layer / weathered layer, fracture basement and fresh basement. It is found in VES location $1,2,3,4,5,6$ and 8 , it covers about $70 \%$ of the total curve type. In the second phase locations $\mathrm{H}$ curve type covers $50 \%$ of the total curve type, A curve type is $30 \%$, HA curve type is $10 \%$, while Q curve type is $10 \%$ in that respect.

Extensive geoelectrical investigations by means of VES technique by Olorunfemi et al., 1991, have shown that a generalized basement complex vertical profile is made up of four geologic layers comprising topsoil, weathered basement, partial weathered/fractured basement and the fresh basement bedrock which are best to yield groundwater.

\subsection{Interpreted borehole log in selected springs in Akoko areas in the first phase of location 1-10 (Fig. 3.1 and Fig. 3.2)}

Location 1: Omidu spring Ikare, longitude $5^{0} 45.262 \mathrm{E}$, latitude $7^{0} 30.508 \mathrm{~N}$ and elevation $204 \mathrm{ft}$. The HA type curve in location 1 comprises four layers which are topsoil, weathered basement, partial weathered/fractured basement and fresh basement. It is $1.4 \mathrm{~m}$ thick which is not significant for good groundwater yield.

Location 2: Along Akungba-Ikare road, longitude $5^{0} 44.689 \mathrm{E}$, latitude $7^{0} 29.365 \mathrm{~N}$ and elevation $357 \mathrm{ft}$.This location also consists of four layers and HA type that is made up of topsoil, weathered basement, potentially weathered, fracture/fresh basement. The potentially weathered basement has a thickness of $3.5 \mathrm{~m}$ which is quite appreciable for groundwater yield.
Location 3: (Opp. CCC parish (Ikare- Akungba road), longitude $5^{0} 44.655 \mathrm{E}$, latitude $7^{0} 29.373 \mathrm{~N}$ and elevation $496 \mathrm{ft}$. The HA type curve consists of four layers that is topsoil, weathered basement, partial weathered/fracture basement and fresh basement. The appreciable thickness of the weathered/fractured basement has led to the groundwater accumulation and discharge to the surface as a spring.

Location 4: (Ayere Abekoko) Ikare, longitude $5^{0}$ 45.337E, latitude $7^{0} 30.628 \mathrm{~N}$ and elevation $479 \mathrm{ft}$. This location has a greater depth and thickness of $11.6 \mathrm{~m}$ $14.6 \mathrm{~m}$, respectively, with an HA curve type appreciable enough for significant groundwater yield.

Location 5: Alafa spring (Supare), longitude $5^{0}$ 41.544E, latitude $7^{0} 27.528 \mathrm{~N}$ and elevation $203 \mathrm{ft}$. This HA curve type comprises four layers: topsoil, weathered basement, partially weathered/fracture basement and fresh basement. The partially weathered/fracture basement has $11.6 \mathrm{~m}$ thickness, which is significant for spring formation and appreciable for groundwater yield.

Location 6: Araromi (Supare), longitude: $5^{0}$ $41.405 \mathrm{E}$, latitude $7^{0} 27.467 \mathrm{~N}$ and elevation $215 \mathrm{ft}$. This HA curve type comprises four layers with the partially/weathered basement having thickness of 4.2 $\mathrm{m}$. This type of spring is a seasonal driven type that dries up during a dry season and accumulates during a wet season.

Location 7: Ogangan (Supare), longitude $5^{0}$ 42.720E, latitude $7^{0} 27.339 \mathrm{~N}$ and elevation $43 \mathrm{ft}$. This A curve type comprises 3 layers, top soil, weathered basement and fresh basement. Due to its less overburden, less depth and the resistivity value, it will not yield sufficient groundwater throughout the year.

Location 8: Araromi (Etioro), longitude: $5^{0}$ 43.370E, latitude $7^{0} 26.374 \mathrm{~N}$ and elevation $78 \mathrm{ft}$. This HA type comprises four layers of a greater depth and thickness of 12.7-7.6 m, respectively.

Location 9: Omi Alafa (Etioro), longitude: $5^{0}$ 43.38E, latitude $7^{0} 26.439 \mathrm{~N}$ and elevation $241 \mathrm{ft}$. This location has A curve type and comprises three layers: topsoil, weathered basement and fresh basement. It is little overburden, with less depth and resistivity value. It may not be able to yield sufficient groundwater for the community.

Location 10: Ebo- Oka Odokunlogbo spring (Iwaro), longitude: $5^{0} 46.444 \mathrm{E}$, latitude $7^{0} 26.37 \mathrm{~N}$ and elevation $688 \mathrm{ft}$. This location has $\mathrm{H}$ curve type and comprises three layers: topsoil, weathered basement and fresh basement, although the depth is a little bit higher than that of an A curve type with little overburden and a resistivity value higher than that of the A curve type. It will yield ground water which may not be sufficient enough.

The borehole log section contains VES stations 1,2,3,4 shown in Figure 4. Three layers were delineated for VES 1, 2, 3 and 4. The first layer is top soil with resistivity of $76.2(\Omega \mathrm{m}), \quad 634.6(\Omega \mathrm{m})$, $352.1(\Omega \mathrm{m})$ and $301.4(\Omega \mathrm{m})$ to thickness of $0.9 \mathrm{~m}$, $0.5 \mathrm{~m}, 0.8 \mathrm{~m}$ and $0.5 \mathrm{~m}$. 


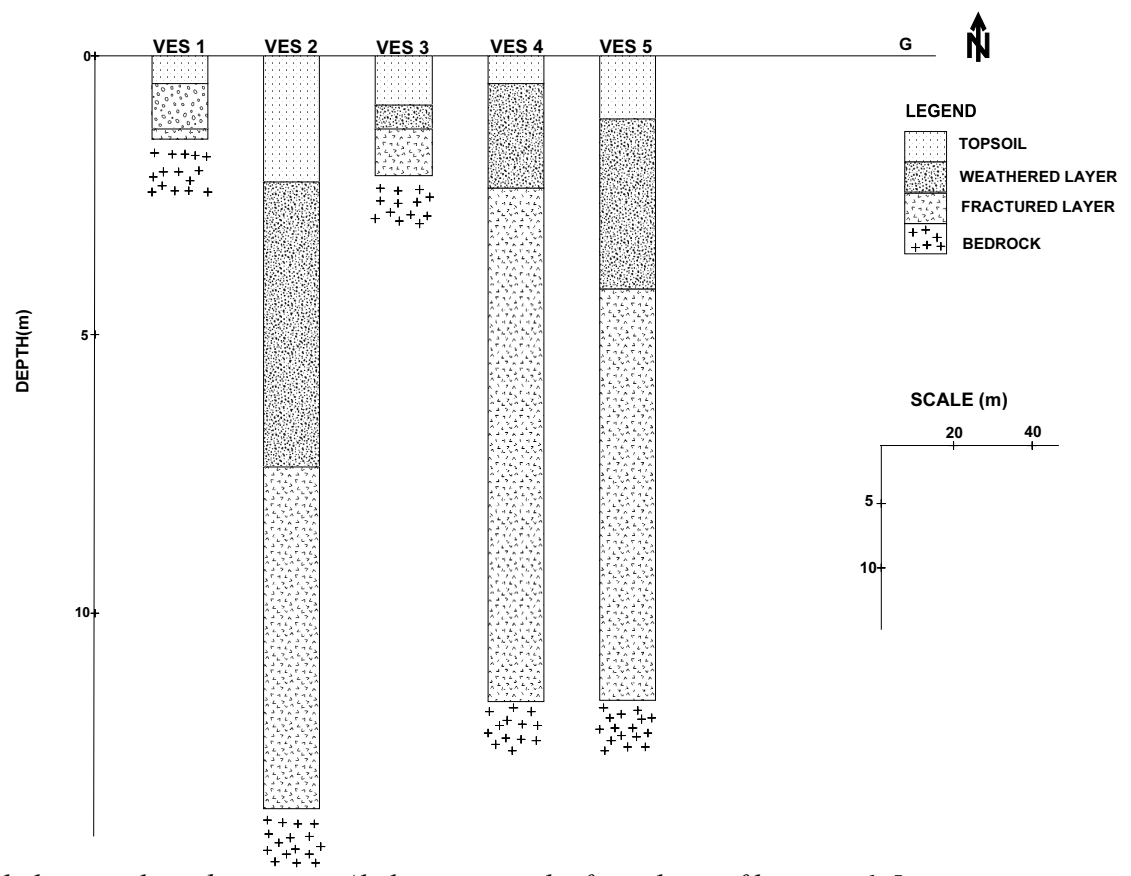

Fig. 3.1. Borehole log in selected spring in Akoko areas in the first phase of location 1-5

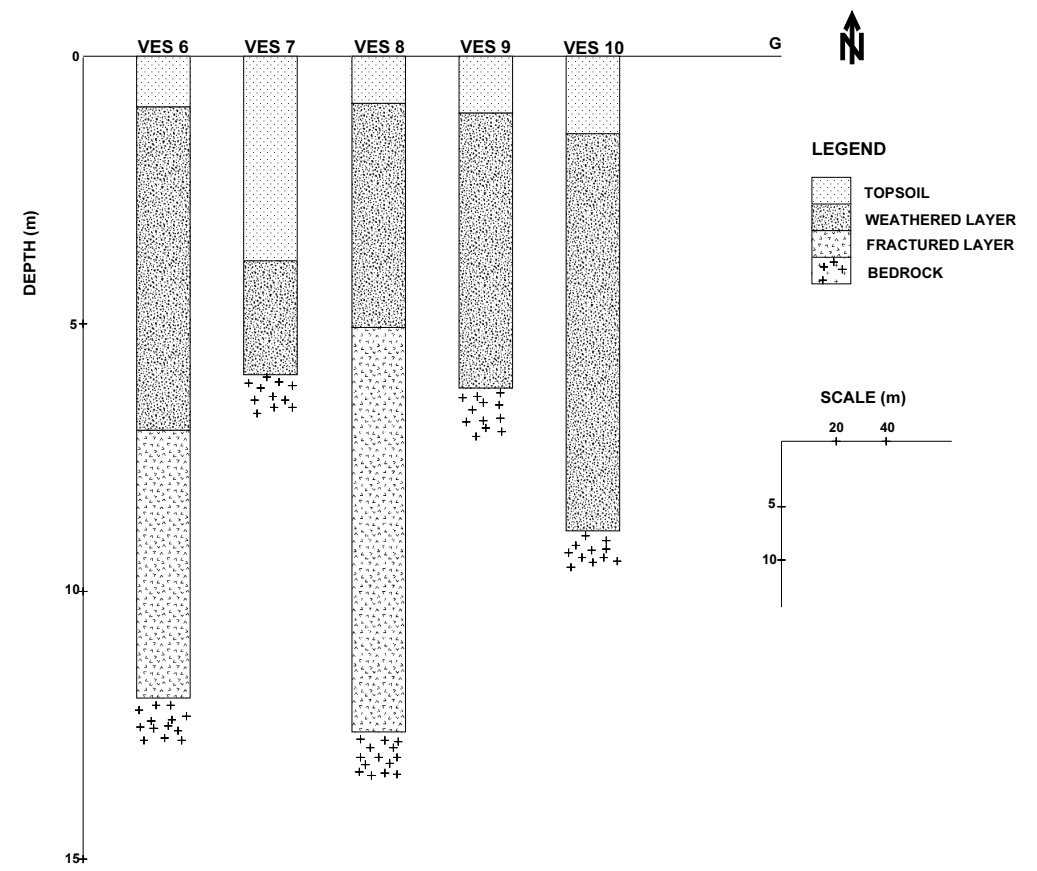

Fig. 3.2. Borehole log in selected spring in Akoko areas in the first phase of location 6-10

4.2 Interpreted borehole log in selected springs in Akoko areas in the second phase of location 1-10

Their second layer is a weathered layer with resistivity of $200.9(\Omega \mathrm{m}), 100(\Omega \mathrm{m}), 197.3(\Omega \mathrm{m})$ and $256.1(\Omega \mathrm{m})$ and thickness of $2.7 \mathrm{~m}, 3.1 \mathrm{~m}, 5.0 \mathrm{~m}$ and $2.3 \mathrm{~m}$. When the weathered layer is significantly thick, it has the capacity to constitute an aquifer unit and to discharge as a spring to the surface through the fracture pathway. A third layer is fresh basement which has resistivity values of $285.3(\Omega \mathrm{m})$, $170.8(\Omega \mathrm{m}), 626.6(\Omega \mathrm{m})$ and $4574.2(\Omega \mathrm{m})$ with an infinite thickness because the curve terminated at this layer.
A borehole log section contains VES stations $5,6,7,8$ (Figure 4). Three layers were delineated in VES 6, 7 and 8, while four layers were observed in VES 5. For VES 5, 6, 7 and 8, the first layer is topsoil with resistivity of $229(\Omega \mathrm{m}), \quad 421.9(\Omega \mathrm{m})$ and $121.4(\Omega \mathrm{m})$ to thickness of $0.8 \mathrm{~m}, 1.1 \mathrm{~m}$ and $0.7 \mathrm{~m}$. Their second layer is a weathered layer with resistivity of $109.1(\Omega \mathrm{m}), 34.4(\Omega \mathrm{m})$ and $72.2(\Omega \mathrm{m})$ to thickness of $4.6 \mathrm{~m}, 5 \mathrm{~m}$ and $2.5 \mathrm{~m}$.

For VES 6, 7, and 8 their third layer which is the basement of $2186.7(\Omega \mathrm{m}), 1447.5(\Omega \mathrm{m})$ and 446.4 $(\Omega \mathrm{m})$ to infinite thickness because the curve terminated at this layer. VES 5 was inferred with resistivity of $152.1(\Omega \mathrm{m})$ for topsoil, $31.3(\Omega \mathrm{m})$ for the weathered layer, with low resistivity usually for clay 
and $1146.4(\Omega \mathrm{m})$ for the fractured zone which it is also the main aquifer unit, to thickness of $0.4 \mathrm{~m}, 1.1 \mathrm{~m}$, and $2.4 \mathrm{~m}$ and the fourth layer was inferred with resistivity of $22918.5(\Omega \mathrm{m})$ with infinite thickness. Therefore, both the second layer of VES 6, which is the weathered layer, is taken as the major aquifer unit for groundwater development and the third layer of VES 5 , which is the fractured basement, constitute spring water.

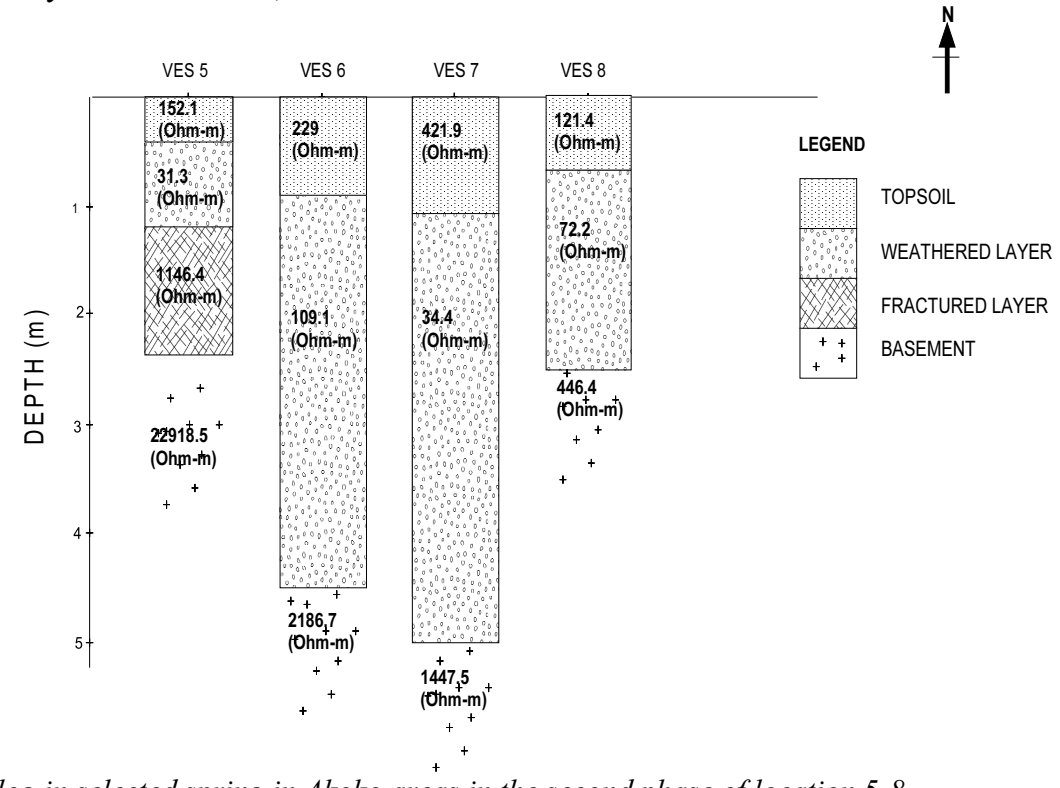

Fig. 4. Borehole log in selected spring in Akoko areas in the second phase of location 5-8

This result contains VES 9 and 10 (Figure 5). Three layers were observed. The first layer which is top soil has resistivity of $191.8(\Omega \mathrm{m})$ and $109.9(\Omega \mathrm{m})$ with thickness of $0.7 \mathrm{~m}$ to $0.5 \mathrm{~m}$. Their second layer which is weathered layer was inferred with resistivity of $185.0(\Omega \mathrm{m})$ to $47.6(\Omega \mathrm{m})$ with appreciable thickness of $8.0 \mathrm{~m}$ and $2.0 \mathrm{~m}$. Beyond this layer there is the basement complex with resistivity of $1456.0(\Omega \mathrm{m})$ to $2056(\Omega \mathrm{m})$ to infinite thickness.

Therefore, VES 9 constitutes the major aquifer unit for spring water development for weathered layer at high resistivity and VES 10 has low resistivity, which is clay i.e. not good groundwater development due to permeability.

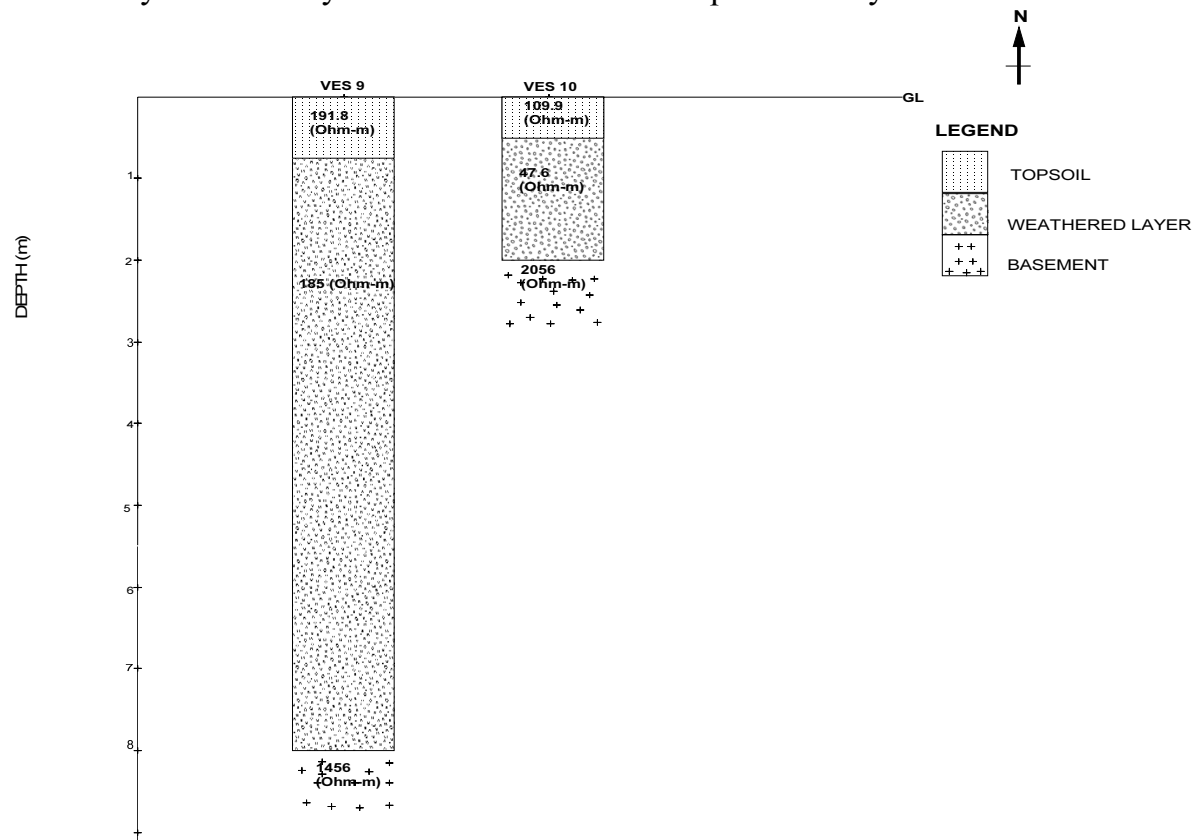

Fig. 5. Borehole log in selected spring in Akoko areas in the second phase of location 9-10

\subsection{Physico-chemical results}

Table 1 shows WHO 2004 drinkable water standards, adopted in comparison the results of physico-chemical analysis of twenty (20) samples taken in the study areas, as shown in Table 2 . The bar chart format is represented in Figure 6. WHO 2004 results are compare to those obtained from selected springs in the study area, and there is little variation in the values of $\mathrm{pH}$, temperature and $\mathrm{EC}$ of the sample.

Turbidity is also of little variation, which is a measure of relative clarity of liquid (Matheis G. 
1982). Turbidity of the water samples is compared to that of WHO 2004, and some discrepancies in the range of 0.01 to 0.10 have been observed which show that samples 4, 7 and 10 have the least value and are clearer when compared to sample 6 whose value is 0.010. The analysis has shown that water samples from the selected springs do not exceed the WHO limit for the water quality standard.

Table 1. is showing the WHO standard 2004

\begin{tabular}{||l|l|l||}
\hline \multicolumn{1}{|c|}{ Analysis } & \multicolumn{1}{|c|}{ Acceptable level } & \multicolumn{1}{c|}{ Effect } \\
\hline Total Dissolved Solid[TDS] & Max 1000 & Stomach discomfort \\
\hline Temperature & $25^{0} \mathrm{c}-26^{0} \mathrm{c}$ & $\begin{array}{l}\text { Bone disease pain and tenderness of the bone, } \\
\text { children may get mottled teeth. }\end{array}$ \\
\hline Turbidity & Max 25 & Nausea, cramps, diarrhoea and associated head aches \\
\hline $\mathrm{PH}$ & $6.5-8.5$ & Rusting and cancer \\
\hline Electrical Conductivity & Max $10 \mu \mathrm{s} / \mathrm{cm}$ & $\begin{array}{l}\text { Anaemia; liver, kidney or spleen damage, changes in } \\
\text { blood. }\end{array}$ \\
\hline $\begin{array}{l}\text { Biochemical Oxygen Demand } \\
\text { [BOD] }\end{array}$ & Limit $6 \mathrm{mg} / \mathrm{l}$ & Liver cancer \\
\hline Chemical Oxygen Demand [COD] & $\begin{array}{l}\text { Limit 3-6mg/l in Urban and } \\
\text { Rural area respectively }\end{array}$ & Liver cancer \\
\hline
\end{tabular}

Table 2. showing chemical analysis of samples

\begin{tabular}{|c|l|l|l|l|l|l|l||}
\hline S/N & Ph & Temp & Ec & Turbidity & TDS & BOD & COD \\
\hline 1 & 6.92 & 25 & $2.4 \times 10^{2}$ & 0.02 & 0.25 & 3.5 & 4.8 \\
\hline 2 & 6.94 & 25 & $1.3 \times 10^{2}$ & 0.03 & 0.02 & 3.2 & 3.2 \\
\hline 3 & 6.91 & 25 & $2.2 \times 10^{2}$ & 0.05 & 0.33 & 3.4 & 6.4 \\
\hline 4 & 7.02 & 26.6 & $1.4 \times 10^{2}$ & 0.01 & 0.44 & 4.1 & 5.6 \\
\hline 5 & 6.93 & 25.8 & $1.2 \times 10^{2}$ & 0.06 & 0.36 & 3.3 & 6.4 \\
\hline 6 & 7.00 & 25.2 & $2.1 \times 10^{2}$ & 0.010 & 0.54 & 2.8 & 6.4 \\
\hline 7 & 7.08 & 25.3 & $2.3 \times 10^{2}$ & 0.01 & 0.19 & 2.6 & 4.0 \\
\hline 8 & 7.11 & 25.3 & $1.5 \times 10^{2}$ & 0.03 & 0.55 & 3.3 & 4.8 \\
\hline 9 & 6.86 & 25.0 & $1.4 \times 10^{2}$ & 0.03 & 0.09 & 4.3 & 5.6 \\
\hline 10 & 7.12 & 25.0 & $1.3 \times 10^{2}$ & 0.01 & 0.54 & 4.8 & 3.2 \\
\hline
\end{tabular}

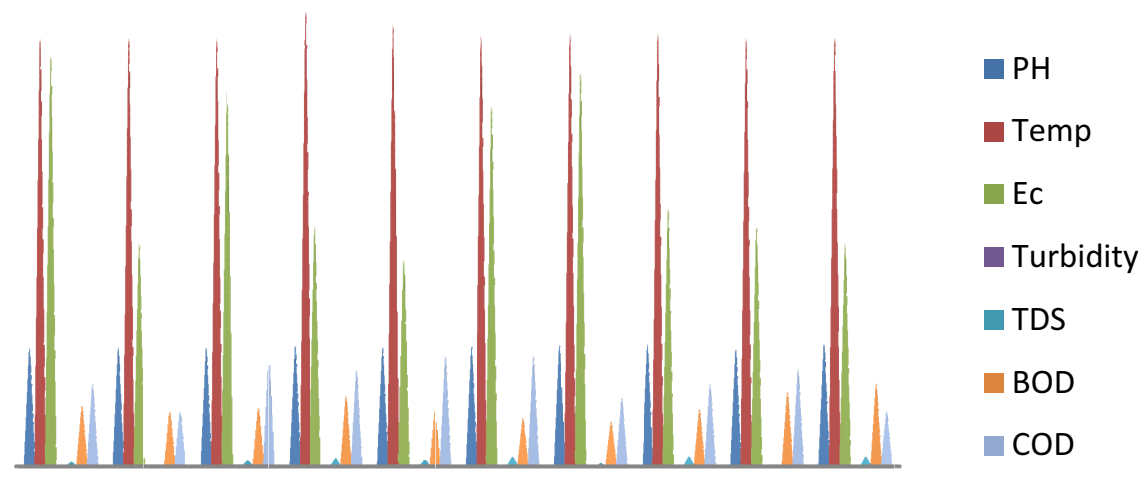

Fig. 6. Bar chart showing results of physico-chemical analysis

Spring water exhibits little variation in values of the total dissolved solid (TDS). Concentration with sample whose TDS concentration value is $0.02 \mathrm{mg} / \mathrm{l}$ which is the lowest concentration value, and sample 8 has the highest concentration value and it may need little treatment before it can be used for human consumption. The results analysed were compared to the WHO standard and they showed that TDS did not exceed the maximum limit for potability.

Results of the organic matter in water have been measured as biochemical oxygen demand (BOD) and chemical oxygen demand (COD). Two of these parameters are two common measures of the water quality that reflect the degree of organic matter pollution of water BOD is a measure of the quantity of dissolved oxygen (DO) in $\mathrm{mg} / \mathrm{l}$ necessary for decomposition of organic matter by micro-organisms such as bacteria. COD is a water quality measure used not only to measure the amount of biologically active substances such as bacteria but also biologically inactive organic matter in water. It is an oxygen equivalent of the total organic matter in a water sample that is susceptible to oxidant such as dichromate. COD test results are a good estimate of BOD values. In other cases of the Table there is more COD than BOD. These parameters are used by pollution control boards to assess water pollution by domestic and industrial waste. 
Results of BOD and COD from the study area show that they exceeded the maximum allowable limit of the WHO standard. BOD ranges from 2.8 to 4.1, while COD ranges from 3.2 to 6.4 respectively. The World Health Organization (WHO) recommends a BOD limit of $6 \mathrm{mg} / \mathrm{l}$ for drinking water as shown Table 1. The same is true with the European Union. In view of ease of determination of COD over BOD, China has set the maximum allowable COD $3 \mathrm{mg} / \mathrm{l}$ for drinking water in urban areas and $6 \mathrm{mg} / \mathrm{l}$ in rural areas. The organic pollution of drinking water in the study area indicates that people in these selected areas will be prone to liver cancer, because results of the analyses are greater than the acceptable level. They differ from those in the report by Edema et al (2001) where samples of analyzed drinking water in Abeokuta have unpleasant odour and taste.

\section{Conclusions}

A geophysical survey method involving the use of Vertical Electrical Resistivity Sounding technique was applied in twenty (20) different locations in Akoko area of south-western Nigeria. Results obtained in the study area have revealed that weathered and fractured basement constitutes a major aquifer unit in the area. Fractured basement rock aquifer occurs immediately beneath the weathered basement rock aquifers in most places and serves as the main source of water that springs out as spring water. In addition BOD concentration in spring water within the study area can be considered safe for drinking purposes (with respect to its BOD concentration). As BOD and COD levels in all analyzed samples were lower or higher than the permissible length $(6 \mathrm{mg} / \mathrm{l})$ recommended by WHO location, water from springs 3,5 and 6 is not safe for drinking because of a higher COD concentration than the permissible limit, hence that water requires to be treated before it can be safe for drinking purposes.

\section{References}

Abdullahi Idris-Nda. 2005. Groundwater potential of part of Kushaka Schist belt of North-Central Nigeria. Water Resour. 16, 90-95.

Adelusi, A.O., Igbedi, A.O., And Folarin, S.L. 2000 The geologic mapping of basement structures and its groundwater potential in Ero Area, Ondo State, Southwestern Nigeria. Water Resour. 12, 1-6.

Ako, B.D. 1996. Applied geophysics. The subsurface and treasures. An Inaugural lecture delivered at the Obafemi Awolowo University, Ile-Ife. Inaugural lecture series,

APHA AND JIPHA. 1985. Standard Methods for the Examination of Water and Waste water. $20^{\text {th }}$ Edition. American Public Health Association: Washington, DC. pp.53- 72 .
APHA. 1985. Standard Methods for the Examination of Water and Wastewater. $6^{\text {th }}$ Edition. American Public Health Association: Washington, D.C. pp. 31- 50.

Bala, A.E., Ike, E.C. 2001. The aquifer of the crystalline basement rocks in Gusau are, North-Westerns Nigeria. J. Mining and Geol. 37(2), 177-184.

Barker, R., Blunk, I. And Smith, I. 1996. Geophysical Consideration in the Design of UK National Resistivity Sounding Database. First Break, Vol.14, No 2, pp.45-53.

Bayode, S., 2000. Geophysical characterization of the Iwo migmatite gneiss/granite complex. Its significance to groundwater potential. Unpublished M. Tech Thesis,

Federal University of Technology, Akure, Nigeria. pp: 213. Charrois, J. W. A. 2010. Private drinking water supplies: challenges for public health.

Dada, A, And Ntukekpo, D.S.1997. Pure Water: How Safe? Ultimate Water Technology and Environment. Vol. 1 No. 3, P 8-11.

Edema M.O, Omemu A.M And Faputu O.M, 2001. Microbiology and physico-chemical analysis of different sources of drinking water in Abeokuta,Nigeria.Nigerian Journal of Microbiology.15(1);57-61.

Fenwick, A. 2006.Waterborne Infectious Diseases-Could they be consigned to History? Science 313:1077-1081 $\mathrm{http} / / / \mathrm{dx}$.doi.org/10.1126/science.1127184

Hrudey, S. E., And Hrudey, E. J. 2007. A Nose for Trouble: The Role of Off-flavours in Assuring Safe DrinkingWater. Water Sci. \& Technol., $\quad$ 55(5), 69. http://dx.doi.org/10.2166/wst.2007.185

Ishaku, J. M. 2011. Assessment of groundwater quality index for Jimeta-Yola area, Northeastern Nigeria.

Journal of Geology and Mining.

Macrea R, Robinson R.K And Sadler M.J. 1993.

Encyclopedia of Food Science, Food Technology and Nutrition. Academic Press Publishers, London.P1073-1077

Matheis, G., 1982. The Properties of Ground water. Wiley, New York, pp 25- 28.

Olorunfemi M.O Dan Hassan M And Adekile D.A. 1991. Geophysical Exploration for Ground water in Crystalline Basement Terrain. Journal of Mining and Geology, 27-(2) 71-75.

Oyeku, O.M.,Omowumi, O.J., Kupoluyi, C.F, And Toye, E.O. 2001. Wholesomeness Studies of Water Produced and Sold in Plastic Sachets (Pure Water) in Lagos Metropolis. Nigerian Food Journal 19.63-69

Rahaman, M.A., 1976. Review of the basement geology of southwestern Nigeria. In: Geol. Nigeria. Elizabethan Publi. Co., Nigeria. pp: 41-58.

Rahaman, M.A., 1989. Review of the basement geology of Southwestern Nigeria. In: the geology of Nigeria (eds Kogbe CA) 2nd edition, Rock View, Nigeria Ltd. pp: 538.

Rahaman, M.A., Ocan, O., 1978. On relationships in the Precambrain migmatite gneiss in Nigeria. J. Mining and Geol. 15, 23-33. 
Raymond, F, 1992. Problems of Water. E. B and sons U.K p 126.

Reynolds, K. A., Mena, K. D., And Gerba, C. P. 2008. Risk of waterborne illness via drinking water in the United States. Rev Environ Contam Toxicol, 192,117-58. http://dx.doi.org/10.1007/978-0-387-71724-1_4

UNESCO. (2006). UNESCO water portal newsletter no. 161: Water-related diseases.

W.H.O 2004: Guidelines for Water Quality World Health Organization Recommendation, $2^{\text {nd }}$ Edition pp 231.
W.H.O, 1971. World Health Organization Guild lines for drinking water quality, $3^{\text {rd }}$ Edition. World Health Organization of the United Nation, Rome Italy 1:68

Okpoli C. C. is from the Department of Geology, Adekunle Ajasin University; assistant lecturer.

Main research area:Environmental geophysics

Address: $\quad$ Akungba- Akoko, Ondo State, Nigeria.

Phone: $\quad+2348064488625$

E-mail: $\quad$ okpolicyril@gmail.com

\section{Galimų vandens šaltinių fizikiniai bei cheminiai ir gręžinių pjūvių tyrimai Akoko teritorijoje, Pietų ir Vakarų Nigerijoje}

\section{Cyril Chibueze Okpoli}

Adekunle Ajasin universitetas, Geologijos katedra, Akungba-Akoko, Nigerija

(gauta 2013 m. gegužès mèn., priimta spaudai 2013 m. rugsëjo mèn.)

Šiame darbe, taikant Schlumbergerio konfigūracijos metodą, buvo atliktas geologinis ir fizikinis tyrimas. Nustatyti vandens mèginiu fizikiniai ir cheminiai parametrai dvidešimtyje atrinktų Akoko vietų, Ondo valstijoje, kuri yra ịsikūrusi pietvakarių Nigerijoje. Galimi vandens šaltiniai kartografuojami atsižvelgiant i gylị, storị, varžą ir derlingas nuosėdas. Taikant kompiuterinị iteracini procesą, buvo analizuojami gauti duomenys. Tiriant dirvožemio paviršiaus sudūlèjusị ar išsisluoksniavusį ir giluminị sluoksnius, buvo nubraižytos A, HA ir Q tipinès kreivès. Tiriant gręžinio pjūvị, daugiausia dèmesio buvo skiriama sudūlëjusiam sluoksniui dèl jo pakankamo storio, kuris reikalingas vandens šaltiniams formuotis ir sezoniniam derliui gauti. Surinktu vandens mèginiu fizikiniai ir cheminiai parametrai svyravo taip: $\mathrm{pH}$ - nuo 6,57 iki 7,20; elektros laidumas (EC) - nuo $1.2 \times 10^{2} \mathrm{iki} 4.2 \times 10^{2}(\mathrm{Uhr} / \mathrm{cm})$; ištirpusių medžiagų kiekis - nuo 0,01 iki 0,55 (mg/l); drumstumas nuo $0,01-0,1$; ištirpusio deguonies koncentracija - nuo 7,8 iki 9,6 (mg/l); BOD - nuo 2,8 iki 4,8 (mg/l) ir ChDS 1,6-6,4 (mg/l); temperatūra nuo $25{ }^{\circ} \mathrm{C}$ iki $26{ }^{\circ} \mathrm{C}$. Dauguma tirtu mèginiu atitinka Pasaulinès sveikatos organizacijos (PSO) nustatytas ribines vertes, kurios yra žemesnès negu $10 \mathrm{mg} / \mathrm{l}$, išskyrus ChDS ir temperatūrą, viršijančią PSO rekomenduojamas vertes 3.5 ir 6 vietovėse. Kadangi šiose vietovėse yra padidejęs žmonių sergamumas vėžiu, rekomenduojama prieš vartojant vandenị maisto reikmėms ji pirmiausia išvalyti. 